\title{
Utilization patterns by Angora goats within the plant can- opies of two Acacia shrubs
}

\author{
M. KEITH OWENS
}

\section{Abstract}

Uneven distribution of livestock in large pastures results in some areas receiving more use than the average and some areas receiving little or no use. Six 2-ha experimental pastures on a shallow ridge site were stocked with 2, 4, or 6 Angora goats per ha to reflect different levels of use found in large pastures of south Texas. Two additional pastures on a sandy loam site were stocked with 2 goats per ha. Utilization estimates were made in each pasture using a twig diameter-weight relationship. Estimates of utilization of guajillo (Acacia berlandieri) and blackbrush (A. rigidula) were made in canopy strata which the goats could reach in a quadrupedal stance (low), a bipedal stance (middle), and from the zone above the bipedal stance (high). These measurements were repeated 3 times during the grazing season. Nonlinear regressions of diameter on weight $\left(Y=\mathbf{a X}^{\mathbf{b}}\right)$ collected from plants in control pastures provided a better fit than log-log regressions in almost every instance. Fit index values, which are analogous to $R^{2}$ values for linear equations, ranged from 0.82 to 0.94 for nonlinear equations and from 0.62 to 0.88 for the $\log$-log regressions.

Goats exhibited different grazing strategies by using the canopy strata differently for the 2 plant species. Percent utilization in the middle strata was higher than in either of the other 2 canopy strata within each grazing treatment and for each plant species. Cumulative use in the middle strata for guajillo was $79 \%$ compared to $63 \%$ in the low and $28 \%$ in the high strata. Blackbrush also had highest use in the middle strata with $39 \%$ use compared to 27 and $9 \%$ for the low and high canopies, respectively. By the third sampling period, use of guajillo in the 2 lowest canopy strata declined and use of blackbrush increased over the first 2 sampling periods.

Average grazed twig diameter within each grazing treatment did not vary significantly in the low strata throughout the growing season. On heavily used sites, averaged grazed twig diameter increased in the 2 highest canopy layers as the season progressed. The size of grazed twigs in the middle zone on the heaviest grazed sites was significantly higher than in any other canopy strata.

Key Words: guajillo, blackbrush, grazing pressure, Acacia berlandieri, Acacia rigidula

Domestic herbivores create patterns of utilization within large pastures on several scales. These patterns range in a hierarchical manner from landscapes, pastures, and patches to within individual plant canopies. Utilization patterns within landscapes or pastures may be affected by water location (Andrew 1988), slope (Senft et al. 1985), pasture size (Hacker et al. 1988), grazing treatment (Walker et al. 1989) or a combination of physical characteristics of a pasture (Owens et al. 1991). Uneven distribution of herbivores can result in differential use within plant canopies causing some portions to be used far more than other portions.

Utilization within the canopies of individual plants or of different canopy strata within a pasture has rarely been studied. Knowledge of utilization within canopy strata would be useful in determining the actual forage composition available to grazing animals

\footnotetext{
Author is assistant professor, Texas Agricultural Experiment Station, 1619 Garne Field Rd., Uvalde, Texas 78801 .

This research was supported by the Texas Agricultural Experiment Station. Report is published with approval of the Director, Texas Agricultural Experiment Station as TA-25546.

Manuscript accepted 22 March 1991.
}

and in assessing the impact of grazing on individual plants. Norton and Johnson (1981) demonstrated that plant size and the amount of time cattle were in a pasture affected the depth of grazing within the canopy of crested wheatgrass (Agropyron desertorum). Other studies have focused on the interaction of diet composition and depth of grazing in white clover-ryegrass swards (Milne et al. 1982) or in other grass-legume mixtures (Barthram and Grant 1984). Utilization within shrub canopy horizons has largely been ignored. Shrub canopies may be relatively large compared to small ruminants such as Angora goats and the whole canopy would not be readily accessible. Canopy strata which are easily accessible, such as close to the ground, should be more heavily utilized than strata which are difficult to reach, such as above the animals' head. Tsiouvaras et al. (1989) recently used this concept investigating the effect of Spanish goats on reducing fuel loads in California forests.

The objective of this study was to determine utilization patterns by Angora goats within the canopies of individual guajillo (Acacia berlandieri Benth.) and blackbrush ( $A$. rigidula Benth.) shrubs. The influence of grazing intensity, plant species, and the amount of time in a pasture on use patterns in plant canopy strata were investigated.

\section{Materials and Methods}

This study was conducted on shallow ridge and sandy loam range sites on the George Lyles ranch near Uvalde, Texas $\left(29^{\circ} 03^{\prime}\right.$ $\left.30^{\prime \prime} \mathrm{N}, 95^{\circ} 54^{\prime} 30^{\prime \prime} \mathrm{W}\right)$. The plant community was dominated by guajillo, blackbrush, shrubby bluesage (Salvia ballotiflora Benth.), and ceniza (Leucophyllum frutescens Gray) and was representative of brush communities of south Texas (Table 1). Soils on the shallow ridge site were friable, very gravelly loams about $35 \mathrm{~cm}$ deep (Olmos series). Soils of the sandy loam site were very friable, fine sandy loams about $38 \mathrm{~cm}$ deep (Duval series). Average annual precipitation for the area is approximately $600 \mathrm{~mm}$ but only 241 $\mathrm{mm}$ fell during the study, which was conducted in 1988.

Eight, 2-ha experimental pastures were stocked with $40 \mathrm{~kg}$ castrated Angora goats in February 1988. Six of the pastures were on a shallow ridge range site and 2 were on a sandy loam site. The shallow ridge sites were stocked at 2,4 , and 6 goats per ha from February through August 1988. The sandy loam sites were stocked at 2 goats per ha. Two replications of each treatment were used. The different stocking rates were not established to determine proper stocking of Angora goats but to reflect the range of grazing pressures found in large pastures in south Texas. The rates represent areas around permanent water sources ( 6 goats per ha) along roads and cenderos ( 4 goats per ha) and traditional stocking rates of the area ( 2 goats per ha). The traditional stocking rates were used on the sandy loam site because the site is common in most pastures but less used by goats than the shallow ridge site.

Utilization of the 2 dominant shrubs, guajillo and blackbrush, was estimated using a twig diameter-weight relationships in March, June, and August to determine the influence of the length of the grazing period on utilization patterns. The patterns were investigated by estimating utilization in 3 canopy layers. The first layer included vegetation the goats could graze in a quadrupedal stance (low, $<0.75 \mathrm{~m}$ ), the second layer included vegetation the goats could reach in a bipedal stance (middle, $0.75-1.5 \mathrm{~m}$ ), and the 
Table 1. Shrub cover and composition of the experimental pastures on the George Lyles Ranch.

\begin{tabular}{|c|c|c|c|c|c|c|c|c|}
\hline \multirow[b]{2}{*}{ Species } & \multicolumn{4}{|c|}{ Percent cover grazing treatment } & \multicolumn{4}{|c|}{ Percent composition grazing treatment } \\
\hline & 21 & $2^{2}$ & $4^{2}$ & $6^{2}$ & $2^{1}$ & $2^{2}$ & $4^{2}$ & $6^{2}$ \\
\hline $\begin{array}{l}\text { Blackbrush } \\
\text { (Acacia rigidula) }\end{array}$ & 5.7 & 11.7 & 8.7 & 12.4 & 8.3 & 16.9 & 9.9 & 15.7 \\
\hline $\begin{array}{l}\text { Ceniza } \\
\text { (Leucophyllum frutescens) }\end{array}$ & 17.0 & 1.0 & 8.0 & 5.8 & 24.6 & 1.4 & 9.1 & 7.3 \\
\hline $\begin{array}{l}\text { Black Dalea } \\
\text { (Dalea frutescens) }\end{array}$ & 0.0 & 3.9 & 9.0 & 0.0 & 0.0 & 5.6 & 10.2 & 0.0 \\
\hline $\begin{array}{l}\text { Elbowbush } \\
\quad \text { (Forestiera pubescens) }\end{array}$ & 0.0 & 5.1 & 6.7 & 6.7 & 0.0 & 7.4 & 7.6 & 8.5 \\
\hline $\begin{array}{l}\text { Guajillo } \\
\text { (Acacia berlandieri) }\end{array}$ & 21.4 & 21.3 & 25.5 & 23.4 & 31.0 & 30.8 & 29.0 & 29.6 \\
\hline $\begin{array}{l}\text { Kidneywood } \\
\text { (Eysenhardtia texana) }\end{array}$ & 1.5 & 2.3 & 3.0 & 0.9 & 2.2 & 3.3 & 3.4 & 1.1 \\
\hline $\begin{array}{l}\text { Shrubby bluesage } \\
\text { (Salvia ballotiflora) }\end{array}$ & 15.4 & 17.3 & 19.6 & 27.7 & 22.3 & 25.0 & 22.3 & 35.0 \\
\hline $\begin{array}{l}\text { Texas persimmon } \\
\text { (Diospyros texana) }\end{array}$ & 7.6 & 5.9 & 7.5 & 1.3 & 11.0 & 8.5 & 8.5 & 1.6 \\
\hline $\begin{array}{l}\text { Whitebrush } \\
\text { (Aloysia gratissima) }\end{array}$ & 0.4 & 0.7 & 0.0 & 0.9 & 0.6 & 1.0 & 0.0 & 1.1 \\
\hline
\end{tabular}

'Sandy loam site

2Shallow ridge site

top layer included vegetation which the goats could only reach by either climbing or bending the branches (high, $>1.5 \mathrm{~m}$ ).

At each sampling time, 100 twigs of each species ranging in diameter from 0.1 to $10.0 \mathrm{~mm}$ were measured with digital calipers and collected from an area adjacent to the experimental pastures. The twigs were oven dried for $48 \mathrm{hr}$ at $50^{\circ} \mathrm{C}$ and weighed to the nearest $0.1 \mathrm{~g}$. Regressions between diameter and weight were calculated using both $\log -\log$ and nonlinear techniques for each species. Regression equations were evaluated using a Fit Index (FI) as described by Tausch and Tueller (1988). The fit index is analogous to the correlation coefficient of linear equations. Destructive sampling and regression line calculation was repeated at each sampling date.

Actual utilization was estimated using the regression equations calculated from the ungrazed plants. Forty-nine points were systematically located in each pasture by dividing the pasture into a 7 $\times 7$ grid. The 2 nearest branches of each species were selected for utilization sampling. The basal diameter of the branch where it joined a larger branch up to a maximum diameter of $10 \mathrm{~mm}$ was used to estimate available forage. The diameter of each grazed distal tip on that branch was then recorded and the weights summed to estimate the amount of browse removed. Utilization was expressed as a ratio of weight removed to total weight of each branch. In this manner, 98 samples of utilization were collected for each combination of sampling date, canopy layer, and pasture. Newly grazed twigs could be identified by the fresh exposed wood rather than the weathered appearance of previously grazed twigs.

\section{Data Analysis}

Data were analyzed using a split-plot analysis of variance. The whole plot consisted of the grazing treatments, plant species and canopy layers. The sub-plot consisted of the 3 sampling periods. The main effects and 2-way interactions within the whole plot were tested using the replication, grazing treatment, plant species, and canopy layer interaction as the error term. The subplot effect of sampling date, 2-way interactions involving sampling date and other variables from the whole plot, and the 3-way interaction of plant species, canopy layer, and sampling date were tested using the model mean square error as the error term. Dependent variables of percent utilization, available forage per branch, weight removed per branch, and grazed twig diameter were analyzed separately. All estimates of dependent variables within a canopy layer for each pasture were averaged prior to analysis. The percent utilization data were arcsine transformed but will be discussed in actual percentages. Tests of significance were at $P=0.05$. Mean separation was calculated using the protected least significant difference procedure at $\alpha=0.05$.

\section{Results}

Regressions using the log of weight and $\log$ of diameter, nonlin-

Table 2. Regression coefficients for twig diameter vs weight for guajillo and blackbrush in March, June, and August 1988.

\begin{tabular}{|c|c|c|c|c|c|}
\hline & \multicolumn{3}{|c|}{ Regression coefficients } & \multirow{2}{*}{$\begin{array}{c}\text { Fit } \\
\text { index }\end{array}$} & \multirow{2}{*}{$\begin{array}{c}\text { Standard } \\
\text { error of } \\
\text { residuals }\end{array}$} \\
\hline & $\mathbf{a}$ & b & c & & \\
\hline \multicolumn{6}{|l|}{ Guajillo } \\
\hline non-linear ${ }^{1}$ & 0.00 & 0.04 & 3.04 & .88 & 6.4 \\
\hline non-linear ${ }^{2}$ & -0.07 & 0.04 & 3.03 & .88 & 6.4 \\
\hline $\log -\log 3$ & -2.45 & 2.56 & 0.00 & .80 & 11.7 \\
\hline \multicolumn{6}{|l|}{ June } \\
\hline non-linear & 0.00 & 0.45 & 2.15 & .82 & 19.4 \\
\hline non-linear & -1.32 & 0.59 & 2.04 & .82 & 19.4 \\
\hline $\log -\log$ & -1.83 & 2.64 & 0.00 & .81 & 21.1 \\
\hline \multicolumn{6}{|l|}{ August } \\
\hline non-linear & 0.00 & 0.20 & 2.54 & .90 & 10.1 \\
\hline non-linear & 2.71 & 0.09 & 2.89 & .90 & 9.5 \\
\hline $\log -\log$ & 0.54 & 1.35 & 0.00 & .68 & 40.5 \\
\hline \multicolumn{6}{|l|}{ Blackbrush } \\
\hline \multicolumn{6}{|l|}{ March } \\
\hline non-linear & 0.00 & 0.05 & 2.95 & .94 & 2.0 \\
\hline non-linear & 0.21 & 0.04 & 3.00 & .94 & 2.1 \\
\hline $\log -\log$ & -2.25 & 2.47 & 0.00 & .88 & 5.2 \\
\hline \multicolumn{6}{|l|}{ June } \\
\hline non-linear & 0.00 & 0.16 & 2.54 & .87 & 15.6 \\
\hline non-linear & -0.37 & 0.18 & 2.49 & .87 & 15.6 \\
\hline $\log -\log$ & -2.57 & 2.89 & 0.00 & .86 & 11.1 \\
\hline \multicolumn{6}{|l|}{ August } \\
\hline non-linear & 0.00 & 0.14 & 2.66 & .88 & 15.4 \\
\hline non-linear & -0.73 & 0.16 & 2.58 & .88 & 15.4 \\
\hline $\log -\log$ & -1.02 & 1.96 & 0.00 & .62 & 43.8 \\
\hline
\end{tabular}

${ }^{1}$ twig weight $=\mathbf{b}$ Diameter ${ }^{c}$

${ }^{2}$ twig weight $=a+b$ Diameter ${ }^{c}$

${ }^{3} \log ($ twig weight) $=a+b \log$ (twig diameter) 

Table 3. Utilization of guajillo and blackbrush by Angora goats in 4 grazing treatments and 3 canopy strata. Values are means (n = 98) of utilization for
each sampling period.

\begin{tabular}{|c|c|c|c|c|c|c|c|c|c|c|}
\hline \multirow{3}{*}{\multicolumn{2}{|c|}{$\begin{array}{l}\text { Grazing treatment } \\
\text { (goats/ha) }\end{array}$}} & \multicolumn{9}{|c|}{ Canopy strata } \\
\hline & & \multicolumn{3}{|c|}{ Quadrupedal stance } & \multicolumn{3}{|c|}{ Bipedal stance } & \multicolumn{3}{|c|}{ Above bipedal stance } \\
\hline & & Mar & Jun & Aug & Mar & Jun & Aug & Mar & Jun & Aug \\
\hline \multicolumn{11}{|c|}{ Guajillo } \\
\hline $2^{1}$ & $\begin{array}{l}\text { Mean } \\
\text { SE }\end{array}$ & $\begin{array}{r}15.9 \\
1.1\end{array}$ & $\begin{array}{r}39.7 \\
1.8\end{array}$ & $\begin{array}{r}25.2 \\
1.5\end{array}$ & $\begin{array}{r}25.1 \\
2.3\end{array}$ & $\begin{array}{r}53.1 \\
2.6\end{array}$ & $\begin{array}{r}32.0 \\
1.9\end{array}$ & $\begin{array}{l}0.6 \\
0.2\end{array}$ & $\begin{array}{l}7.8 \\
1.3\end{array}$ & $\begin{array}{l}6.6 \\
1.6\end{array}$ \\
\hline 2 & $\begin{array}{l}\text { Mean } \\
\text { SE }\end{array}$ & $\begin{array}{l}9.5 \\
0.7\end{array}$ & $\begin{array}{r}21.1 \\
1.6\end{array}$ & $\begin{array}{r}19.5 \\
1.5\end{array}$ & $\begin{array}{l}9.1 \\
1.1\end{array}$ & $\begin{array}{r}35.4 \\
2.3\end{array}$ & $\begin{array}{r}18.0 \\
1.6\end{array}$ & $\begin{array}{l}0.6 \\
0.4\end{array}$ & $\begin{array}{l}2.2 \\
0.7\end{array}$ & $\begin{array}{l}3.5 \\
0.9\end{array}$ \\
\hline 4 & $\begin{array}{l}\text { Mean } \\
\text { SE }\end{array}$ & $\begin{array}{r}17.1 \\
0.9\end{array}$ & $\begin{array}{r}37.1 \\
1.8\end{array}$ & $\begin{array}{r}27.5 \\
1.4\end{array}$ & $\begin{array}{r}27.2 \\
2.1\end{array}$ & $\begin{array}{r}58.5 \\
2.1\end{array}$ & $\begin{array}{r}42.7 \\
1.8\end{array}$ & $\begin{array}{l}1.1 \\
0.4\end{array}$ & $\begin{array}{r}15.4 \\
2.3\end{array}$ & $\begin{array}{r}17.1 \\
2.0\end{array}$ \\
\hline 6 & $\begin{array}{l}\text { Mean } \\
\text { SE }\end{array}$ & $\begin{array}{r}24.3 \\
1.2\end{array}$ & $\begin{array}{r}51.8 \\
1.9\end{array}$ & $\begin{array}{r}47.0 \\
1.7\end{array}$ & $\begin{array}{r}39.6 \\
1.9\end{array}$ & $\begin{array}{r}73.6 \\
1.8\end{array}$ & $\begin{array}{r}60.0 \\
1.7\end{array}$ & $\begin{array}{l}4.4 \\
1.0\end{array}$ & $\begin{array}{r}27.2 \\
3.0\end{array}$ & $\begin{array}{r}37.8 \\
3.1\end{array}$ \\
\hline \multicolumn{11}{|c|}{ Blackbrush } \\
\hline & $\begin{array}{l}\text { Mean } \\
\text { SE }\end{array}$ & $\begin{array}{l}1.6 \\
0.3\end{array}$ & $\begin{array}{l}8.8 \\
1.0\end{array}$ & $\begin{array}{l}5.1 \\
0.6\end{array}$ & $\begin{array}{l}2.4 \\
0.7\end{array}$ & $\begin{array}{l}8.9 \\
1.3\end{array}$ & $\begin{array}{l}8.6 \\
1.1\end{array}$ & $\begin{array}{l}0.0 \\
0.0\end{array}$ & $\begin{array}{l}0.9 \\
0.6\end{array}$ & $\begin{array}{l}0.3 \\
0.2\end{array}$ \\
\hline 2 & $\begin{array}{l}\text { Mean } \\
\text { SE }\end{array}$ & $\begin{array}{l}1.8 \\
0.2\end{array}$ & $\begin{array}{l}8.0 \\
0.9\end{array}$ & $\begin{array}{r}14.1 \\
1.3\end{array}$ & $\begin{array}{l}2.7 \\
0.4\end{array}$ & $\begin{array}{r}13.6 \\
1.3\end{array}$ & $\begin{array}{r}15.3 \\
1.3\end{array}$ & $\begin{array}{l}0.3 \\
0.2\end{array}$ & $\begin{array}{l}3.2 \\
1.1\end{array}$ & $\begin{array}{l}2.7 \\
1.0\end{array}$ \\
\hline 4 & $\begin{array}{l}\text { Mean } \\
\text { SE }\end{array}$ & $\begin{array}{l}3.8 \\
0.6\end{array}$ & $\begin{array}{r}12.7 \\
1.0\end{array}$ & $\begin{array}{r}16.1 \\
1.4\end{array}$ & $\begin{array}{l}3.5 \\
0.6\end{array}$ & $\begin{array}{r}20.4 \\
1.8\end{array}$ & $\begin{array}{r}27.5 \\
1.8\end{array}$ & $\begin{array}{l}0.1 \\
0.1\end{array}$ & $\begin{array}{l}5.1 \\
1.0\end{array}$ & $\begin{array}{l}6.3 \\
1.2\end{array}$ \\
\hline 6 & $\begin{array}{l}\text { Mean } \\
\text { SE }\end{array}$ & $\begin{array}{l}6.4 \\
0.8\end{array}$ & $\begin{array}{r}16.6 \\
1.0\end{array}$ & $\begin{array}{r}23.8 \\
1.2\end{array}$ & $\begin{array}{l}6.4 \\
0.9\end{array}$ & $\begin{array}{r}32.4 \\
1.8\end{array}$ & $\begin{array}{r}37.5 \\
1.7\end{array}$ & $\begin{array}{l}0.6 \\
0.3\end{array}$ & $\begin{array}{l}8.1 \\
1.6\end{array}$ & $\begin{array}{r}11.4 \\
1.6\end{array}$ \\
\hline
\end{tabular}

'Sandy loam site.

ear regressions forced through the origin and nonlinear regressions allowing a y-intercept were calculated. Nonlinear regressions generally provided a higher degree of fit and a lower standard error of the residuals than the log-log regressions. The fit index values of nonlinear regressions ranged from 0.82 to 0.94 and none of the $y$-intercept values were significantly different than zero (Table 2 ). Therefore, equations forcing the line through the origin were used to estimate utilization. Fit index values for $\log$-log regressions ranged from 0.62 to 0.88. The lowest fit index was found in August for both species using log-log regressions. The standard error of the residuals was also much higher for the log-log regressions than for the nonlinear regressions. The Fit Index uses the original data rather than the transformed data to calculate how well an equation fits the data. The typically used $\mathbf{R}^{2}$ refers to the transformed data, which may introduce a bias into data interpretation (Tausch and Tueller 1988).

Utilization on guajillo averaged $26 \%$ for each sampling period but ranged from less than $1 \%$ in the highest canopy layer on the sandy loam site to over $73 \%$ in the middle layer in the highest stocking rate (Table 3). Utilization on blackbrush averaged only $9 \%$ for each sampling period and ranged from less than $1 \%$ to $37 \%$. Cumulative utilization was highest for guajillo in the middle canopy layer (79\%). Vegetation in the low and high strata had 63 and $28 \%$ use, respectively for guajillo. Blackbrush also had the highest use in the middle layer (39\%) compared to the low (27\%) and high (9\%) strata.

Analysis of percent utilization indicated a significant interaction between plant species, canopy layer, and sampling period. Additional interactions between grazing treatment and plant species and grazing treatment and canopy layer were also significant. The model was highly significant $(P<0.001)$ and explained most of the variation in utilization $\left(R^{2}=0.97\right)$.

Increasing stocking rates generally resulted in greater utilization of both plant species (Fig. 1). An interaction between grazing treatment and plant species was significant due to the relatively high utilization found for guajillo in the sandy loam site $(22.7 \%)$ and due to the $104 \%$ increase in utilization from the 2 to 4 goats per ha stocking rates for guajillo compared to the $57 \%$ increase in

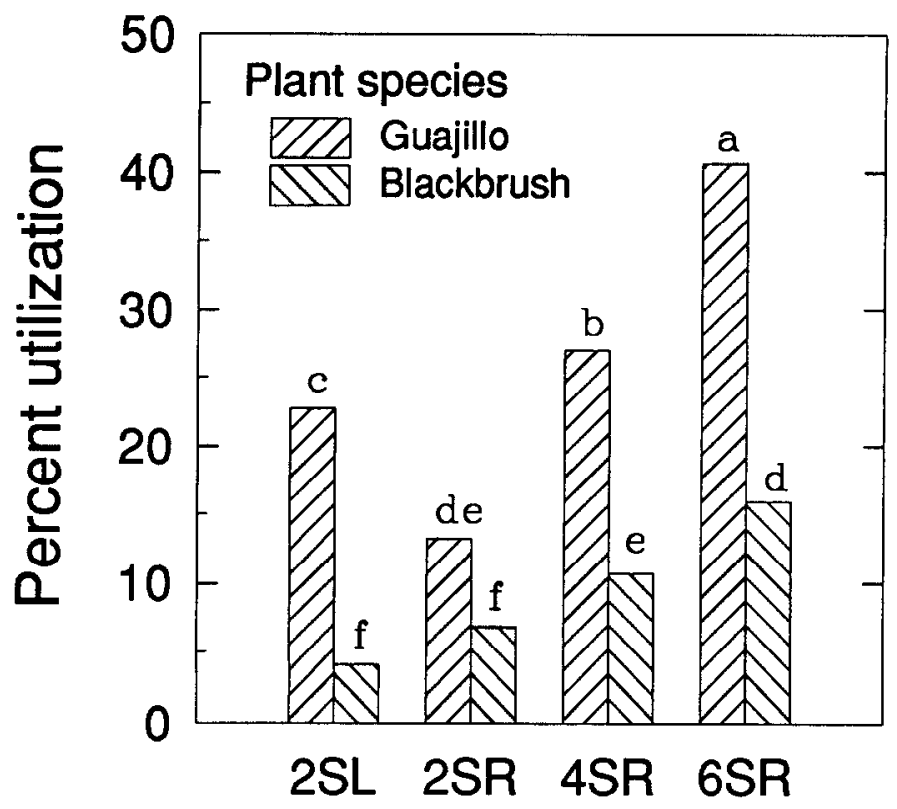

Stocking rate (goats/ha)

Fig. 1. Mean utilization for guajillo and blackbrush at 3 stocking rates on a shallow ridge site and at 1 rate on a sandy loam site. Bars with different letters reflect significant differences at $\boldsymbol{P}<0.05$.

utilization of blackbrush within the same treatments.

Increasing stocking rates also resulted in increased utilization within the 3 canopy heights although utilization within the middle strata increased more rapidly than utilization in either of the other canopy layers resulting in a significant interaction(Fig. 2). In every treatment, the middle canopy layer was the most used strata with an average utilization of $27.2 \%$ compared to the low (18.9\%) and the high canopy layers (6.8\%). An interaction between grazing treatment and utilization in the canopy layers was present due to 


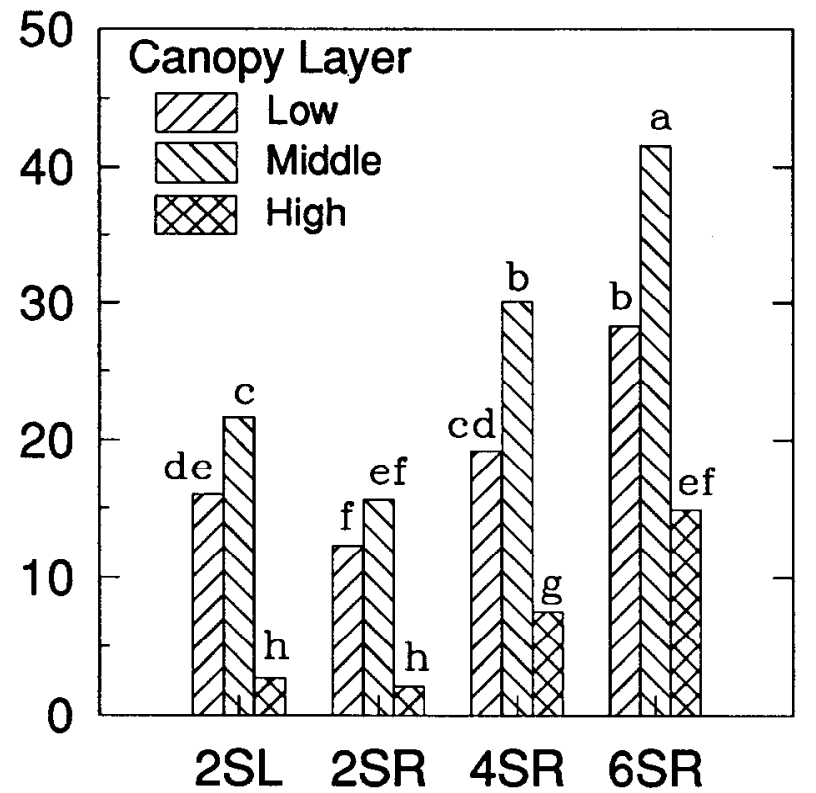

Stocking rate (goats/ha)

Fig. 2. Mean utilization within height classes for 3 stocking rates on a shallow ridge site and for 1 rate on a sandy loam site. Bars with different letters reflect significant differences at $P<0.05$.

the higher utilization found on the sandy loam site than on the shallow ridge site and due to the differences in the relative amount of use within each strata as stocking rates increased on the shallow ridge site.

The effect of sampling period and plant canopy layer on utilization was different for the 2 species resulting in a significant interaction. Utilization was highest in the middle and low canopy layers during the second sampling period for guajillo. By August, utilization in the 2 lowest canopy layers decreased relative to the June sampling date (Fig. 3a). Only in the highest canopy layer did utilization increase as the season progressed. This may have been a result of declining availability of guajillo in the 2 lowest canopy strata by August. Within each sampling period, the middle canopy layer of guajillo always received the heaviest use (Table 3, Fig. 3a). These relationships were not the same for utilization of blackbrush. Throughout the study, utilization steadily increased in each plant canopy layer for blackbrush. After the first sampling period, utilization was always highest in the middle canopy layer (Fig. 3b). The steady increase in utilization of blackbrush may be due to decreased availability of more desirable shrubs such as guajillo and kidneywood (Eysenhardtia texana Scheeb.) (Hervey 1989).

Average branch diameter and weight were significantly different between all of the canopy layers for both guajillo and blackbrush (Table 4). Most of the weight was in the lowest zone for guajillo (48\%) and blackbrush (42\%) compared to the middle strata (33 and $32 \%$, respectively). The actual weight removed per branch by the Angora goats was not significantly different between the lower 2 canopy zones for either species. Only weight removed in the highest layer was significantly lower (Table 4). These results suggest that the goats were actively selecting for forage in the middle zone since the amount of biomass removed was the same although there was less available biomass than in the low zone.

\section{Discussion}

\section{Estimation of Utilization}

Shrub utilization has been estimated for many species using diameter-weight relationships. These relationships have been a) Guajillo

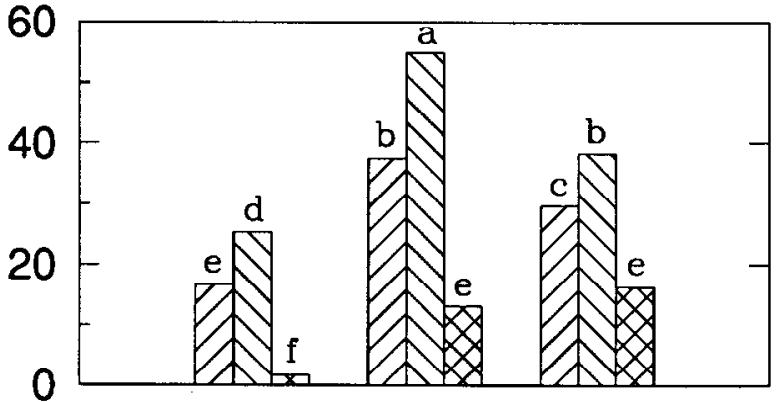

b) Blackbrush

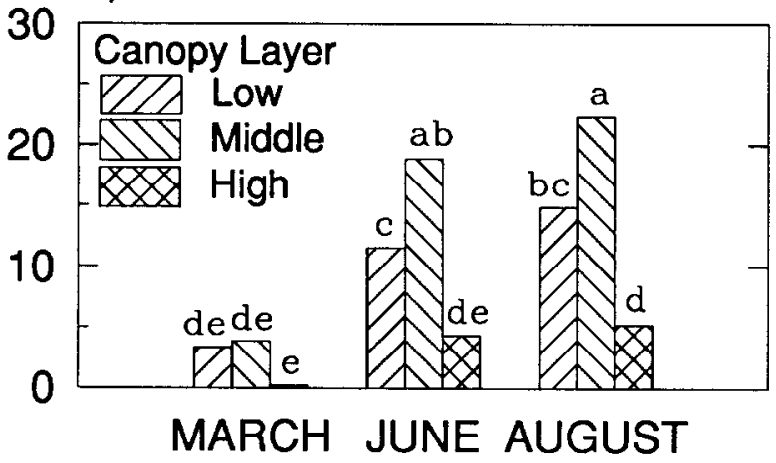

\section{Month}

Fig. 3. Mean utilization of a) guajillo and b) blackbrush within 3 height classes at the beginning, middle, and end of a February-August grazing season. Bars with different letters within each species reflect significant differences at $P<0.05$.

Table 4. Twig morphological characteristics of guajillo and blackbrush within 3 canopy layers.

\begin{tabular}{lccccc}
\hline \hline & $\begin{array}{c}\text { Base } \\
\text { branch } \\
\text { diameter }\end{array}$ & $\begin{array}{c}\text { Grazed } \\
\text { twig } \\
\text { diameter }\end{array}$ & $\begin{array}{c}\text { Base } \\
\text { weight } \\
\text { per } \\
\text { branch }\end{array}$ & $\begin{array}{c}\text { Weight } \\
\text { removed } \\
\text { per } \\
\text { branch }\end{array}$ & $\begin{array}{c}\text { Number } \\
\text { of } \\
\text { grazed } \\
\text { twigs }\end{array}$ \\
\hline $\begin{array}{l}\text { Guajillo } \\
\text { Quadrupedal }\end{array}$ & $7.6 \mathrm{a}$ & $2.3 \mathrm{a}$ & $31.6 \mathrm{a}$ & $8.9 \mathrm{a}$ & $4.2 \mathrm{a}$ \\
Bipedal & $6.4 \mathrm{c}$ & $2.4 \mathrm{a}$ & $21.5 \mathrm{~b}$ & $9.4 \mathrm{a}$ & $2.9 \mathrm{~b}$ \\
Above bipedal & $4.7 \mathrm{e}$ & $0.6 \mathrm{c}$ & $12.2 \mathrm{~d}$ & $1.6 \mathrm{c}$ & $1.3 \mathrm{~d}$ \\
Blackbrush & & & & & \\
Quadrupedal & $7.1 \mathrm{~b}$ & $1.3 \mathrm{~b}$ & $23.3 \mathrm{~b}$ & $2.0 \mathrm{~b}$ & $3.0 \mathrm{~b}$ \\
Bipedal & $6.3 \mathrm{c}$ & $1.3 \mathrm{~b}$ & $17.7 \mathrm{c}$ & $2.6 \mathrm{~b}$ & $2.6 \mathrm{c}$ \\
Above bipedal & $5.5 \mathrm{~d}$ & $0.3 \mathrm{~d}$ & $14.6 \mathrm{~cd}$ & $0.5 \mathrm{~d}$ & $1.2 \mathrm{~d}$ \\
\hline
\end{tabular}

Means followed by different letters in the same column were significantly different from each other at $P<0.05$.

based on a variety of regression techniques. Ruyle et al. (1983) used a quadratic equation to estimate utilization of snowberry (Symphoricarpos oreophilus) in Utah, Tsiouvaras (1987) used both linear and parabolic equations to estimate use on Kermes oak (Quercus coccifera) in Greece and Mahgoub et al. (1988) used linear equations to estimate biomass of hairy mountain mahogany (Cercocarpus breviflorus). Nonlinear regression techniques have not been used to estimate utilization of shrubs. However, the advantages of nonlinear regressions in biological relationships have been shown (Payandeh 1983). Johnson et al. (1988) estimated biomass of ungrazed crested wheatgrass and Tausch and Tueller (1988) estimated phytomass of single leaf pinyon (Pinus monophylla) using a variety of regression techniques and found that 

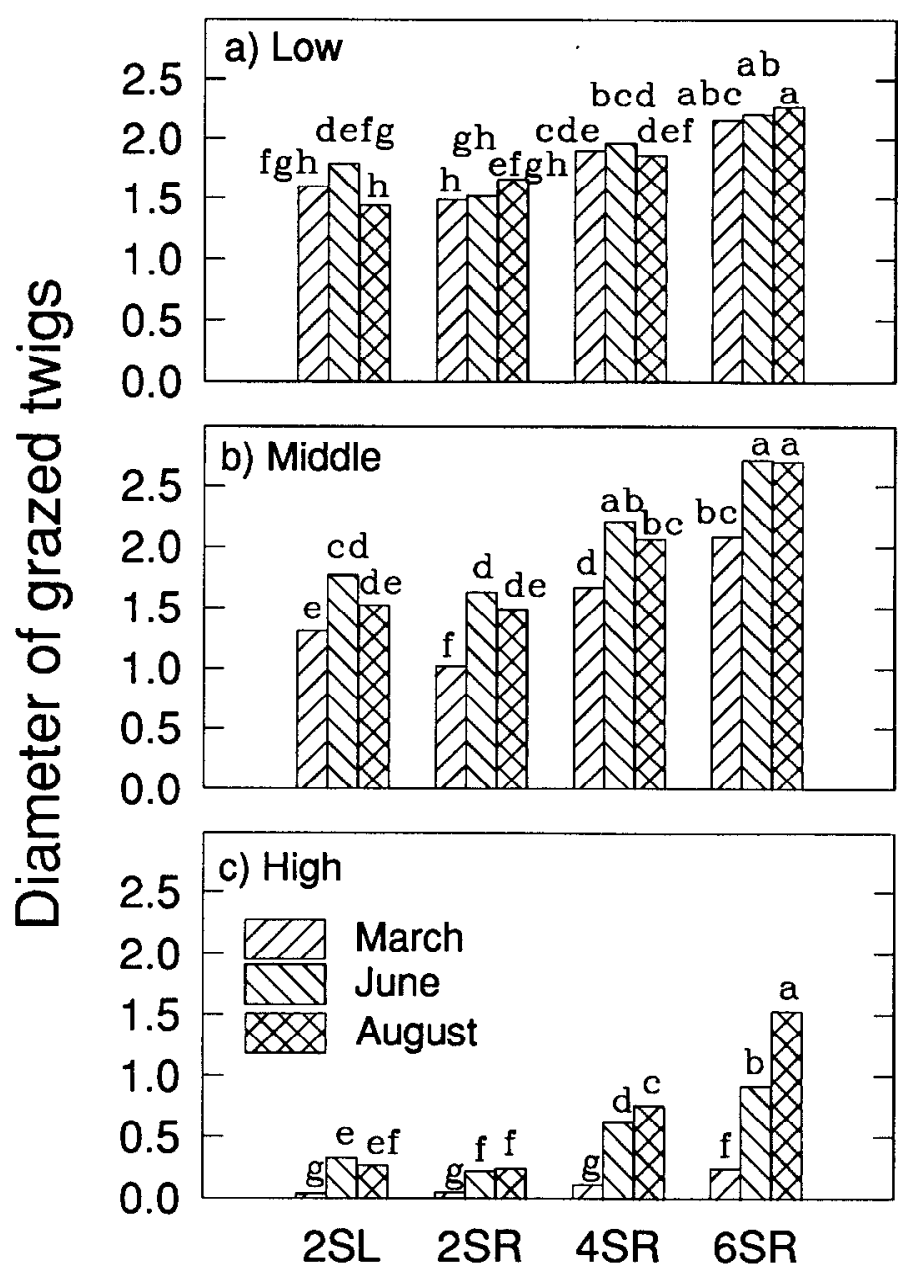

\section{Stocking rate (goats/ha)}

Fig. 4. Mean grazed twig diameters at 3 points in the grazing season within 3 height classes for 3 stocking rates on a shallow ridge site and for 1 rate on a sandy loam site. Bars with different letters within each canopy strata reflect significant differences at $P<0.05$.

nonlinear regressions typically gave the best fit with the lowest standard errors of the estimates. In this study, nonlinear regressions provided a higher fit index and lower standard error than the log-log regressions in almost every instance for both guajillo and blackbrush. This was particularly true when estimating the weight of large diameter twigs. Log-log regression equations underestimated the weight of twigs over $6 \mathrm{~mm}$ diameter for both plant species. Estimates of the amount of biomass available on large branches would be biased downward using a log-log regression. With available forage underestimated, actual utilization would be overestimated for large branches. This problem was not apparent for the nonlinear regressions.

\section{Utilization Distribution}

Guajillo experienced higher utilization than blackbrush in all of the grazing treatments (Fig. 1). This is probably a result of a combination of factors. Guajillo has a higher average in vitro dry matter digestibility than blackbrush during the growing season (41.1 vs $29.8 \%$, respectively, Varner et al. 1979). Crude protein was also higher for guajillo than blackbrush (24.5 vs 17.8 , respectively) during the summer period (Varner et al. 1979). The physical structure of large thorns and small leaves on blackbrush rather than the large leaves and small thorns of guajillo may have provided an impediment to grazing. Cooper and Owen-Smith (1986) suggested that plant spinescence should restrict the intake rates of large mammals and reduce the utilization of mechanically defended plants. In a companion study with these 2 plant species, Hervey (1989) reported that Angora goats always selected guajillo before blackbrush during field experiments and during preference trials conducted in pens. Instantaneous intake rates were lower for blackbrush than for guajillo, which reflects the differences in thorn and leaf size. Consequently, guajillo contributed between 64 and 94\% of the composition of goat diets between June and August on these pastures whereas blackbrush contributed only 2 to $17 \%$ (Hervey 1989).

\section{Utilization Patterns}

Angora goats were found to use the canopy strata which could be reached in a bipedal stance at a significantly higher rate than the other canopy strata. The differentiation of use within vertical canopy layers has been noted in other plant communities as well but is usually a result of having numerous types of grazing animals present (Du Toit 1990). In a recent study, Tsiouvaras et al. (1989) used Spanish goats to reduce fuel levels in brushland and fuelbreaks in coastal California. On both of those sites, utilization was higher in $0.5-1.5 \mathrm{~m}$ zone than in the $<0.5 \mathrm{~m}$ zone. The $0.5-1.5 \mathrm{~m}$ zone approximately corresponds to the bipedal stance layer of this study. On the fuelbreak site, utilization in the upper zone was almost twice as high as in the lower zone. A possible explanation for differential use between the 2 canopy zones was that about $63 \%$ of the current seasons growth was in the upper zone (Tsiouvaras et al. 1989). The high use found in the upper zone could therefore have been a reflection of forage availability rather than selection for a canopy zone by the goats.

Morphological differences between the canopy layers were the probable cause of observed differences in utilization patterns. Goats primarily used new branches in each of the canopy layers and there was no reason to hypothesize the nutritional values of twigs should vary between canopy layers. All of these shrubs were top-killed by freezing in 1984 and consisted of an even aged stand of shrubs. Twig diameter decreased significantly as the height of the canopy layer increased (Table 4). The lowest layer had significantly larger twig diameters than other layers for both species. The mean twig diameter grazed did not differ between the low and middle canopy layers within each species. The lower utilization observed in the low zone was therefore a reflection of a large base diameter which had the net effect of increasing the denominator of the utilization calculation. Angora goats actually grazed twigs to about $2.4 \mathrm{~mm}$ for guajillo and $1.3 \mathrm{~mm}$ for blackbrush regardless of where the twig was located below $1.5 \mathrm{~m}$ height. The selectivity noted for the middle layer was a reflection of the smaller twig diameters found in that zone compared to the low layer of the plant canopy.

The pattern of how Angora goats grazed in a brush community is clearly demonstrated by the distribution of grazed twig diameters (Fig. 4). In the low zone of the plant canopy, the mean diameter of grazed twigs did not increase during the grazing period within each stocking rate. As stocking rate increased, the mean grazed twig diameter increased up to $2.3 \mathrm{~mm}$ but the increase was not related to the length of the grazing period. At low goat densities on the sandy loam and shallow ridge site, the diameter of grazed twigs was significantly higher in the low strata zone than in the middle strata zone at the March sample. As the season progressed, the mean diameter of the grazed twigs was not related to where the twig occurred under $1.5 \mathrm{~m}$. Goats only occasionally grazed in the highest plant canopy zones at the low stocking rate.

When goat density increased, a different grazing strategy became evident. Goats began to use the entire plant canopy below $1.5 \mathrm{~m}$ immediately. The diameter of grazed branches was equal for 
the 2 lowest canopy zones in March but as the season progressed the diameter of grazed branches increased in the bipedal stance zone. Only in the highest canopy zone within the 4 and 6 goats per ha treatments did grazed twig diameter increase in a stepwise fashion throughout the grazing period. Available forage for the Angora goats was therefore conditional upon the number of goats using the area and the length of time the pasture was used.

\section{Conclusions}

The grazing strategy exhibited by goats was affected by the number of goats in a pasture. With a low density of goats, the canopy below $1.5 \mathrm{~m}$ was evenly used. As goat density incresed, utilization in the $0.75-1.5 \mathrm{~m}$ zone increased at a faster rate than in any other canopy zones. Active selection for forage in this zone was evident. Goats also used larger diameter twigs in the $0.75-1.5 \mathrm{~m}$ zone than in any other zone. The changing twig diameters grazed and canopy zone used by Angora goats illustrate the complexity of estimating available forage for grazing animals.

\section{Literature Cited}

Andrew, M.H. 1988. Grazing impact in relation to livestock watering points. Trends in Ecology and Evolution 3:336-339.

Barthram, G.T., and S.A. Grant. 1984. Defoliation of ryegrass-dominated swards by sheep. Grass and Forage Sci. 39:211-219.

Cooper, S.M., and N. Owen-Smith. 1986. Effects of plant spinescence on large mammalian herbivores. Oecologia 68:440-455.

Du Toit, J.T. 1990. Feeding-height stratification among African browsing ruminants. Afr. J. Ecol. 28:55-61.

Hacker, R.B., B.E. Norton, M.K. Owens, and D.O. Frye. 1988. Grazing of crested wheatgrass, with particular reference to effects of pasture size. J. Range Manage. 41:73-78.

Hervey, R.L. 1989. Effects of grazing pressure by Angora goats on intra/ interspecific foraging competition with white-tailed deer. M.S. Thesis. Texas A\&M Univ., College Station.
Johnson, P.S., C.L. Johnson, and N.E. West. 1988. Estimation of phytomass for ungrazed crested wheatgrass plants using allometric equations. J. Range Manage. 41:421-425.

Mahgoub, E.F., R.D. Pieper, and M. Ortiz. 1988. Use of leader lengths and diameters to estimate production and utilization of Cercocarpus breviflorus. J. Range Manage. 41:153-155.

Milne, J.A., J. Hodgson, R. Thompson, W.G.Souter, and G.T. Barthram. 1982. The diet ingesta by sheep grazing swards differing in white clover and perennial ryegrass content. Grass and Forage Sci. 37:209-218.

Norton, B.E., and P.S. Johnson. 1981. Pattern of defoliation by cattle grazing crested wheatgrass pastures. Proc. XIV Intern. Grassl. Congr. pp. $462-464$.

Owens, M.K. Launchbaugh, K.L., and J.W. Holloway. 1991. Pasture characteristics affecting spatial distribution of utilization in mixed brush communities. J. Range Manage. 44:118-123.

Payandeh, B. 1983. Some applications of nonlinear regression models in forestry research. Forest. Chron. 59:244-248.

Ruyle, G.B., J.E. Bowns, and A.F. Schlundt. 1983. Estimating snowberry (Symphoricarpos oreophilus) utilization by sheep from twig diameterweight relations. J. Range Manage. 36:472-474.

Senft, R.L., L.R. Rittenhouse, and R.G. Woodmansee. 1985. Factors influencing patterns of cattle grazing hehavior on shortgrass steppe. $J$. Range Manage. 38:82-87.

Tausch, R.J., and P.T. Tueller. 1988. Comparison of regression methods for predicting singeleaf pinyon phytomass. Great Basin Natur. 48:39-45.

Tsiouvaras, C.N. 1987. Ecology and management of Kermes oak (Quercus coccifera L.) shrublands in Greece: A review. J. Range Manage. 40:542-546.

Tsiouvaras, C.N., N.A. Havlik, and J.W. Bartolome. 1989. Effects of goats on understory vegetation and fire hazard reduction in a coastal forest in California. Forest Sci. 35:1125-1131.

Varner, L.W., L.H. Blankenship, and G.W. Lynch. 1979. Seasonal changes in nutritive value of food plants in south Texas. Proc. Annu. Conf. Southeastern Assoc. Fish \& Wildl. Agencies. 31:99-106.

Walker, J.W., R.K. Heitschmidt, and S.L. Dowhower. 1989. Some effects of a rotational grazing treatment on cattle preference for plant communities. J. Range Manage. 42:143-148. 